\title{
Timing the end-Triassic mass extinction: First on land, then in the sea?
}

\author{
József Pálfy* Collegium Budapest, Institute for Advanced Study, H-1014 Budapest, Hungary \\ James K. Mortensen Department of Earth and Ocean Sciences, University of British Columbia, Vancouver, \\ British Columbia V6T 1Z4, Canada \\ Elizabeth S. Carter Department of Geology, Portland State University, Portland, Oregon 97207-0751, USA \\ Paul L. Smith ] Department of Earth and Ocean Sciences, University of British Columbia, Vancouver, \\ Richard M. Friedman $\_$British Columbia V6T 1Z4, Canada \\ Howard W. Tipper Geological Survey of Canada, Vancouver, British Columbia V6B 5J3, Canada
}

\begin{abstract}
The end-Triassic marks one of the five biggest mass extinctions, but current geologic time scales are inadequate for understanding its dynamics. A tuff layer in marine sedimentary rocks encompassing the Triassic-Jurassic transition yielded a U-Pb zircon age of 199.6 $\pm 0.3 \mathrm{Ma}$. The dated level is immediately below a prominent change in radiolarian faunas and the last occurrence of conodonts. Additional recently obtained $\mathrm{U}-\mathrm{Pb}$ ages integrated with ammonoid biochronology confirm that the Triassic Period ended ca. $200 \mathrm{Ma}$, several million years later than suggested by previous time scales. Published dating of continental sections suggests that the extinction peak of terrestrial plants and vertebrates occurred before 200.6 Ma. The end-Triassic biotic crisis on land therefore appears to have preceded that in the sea by at least several hundred thousand years.
\end{abstract}

Keywords: mass extinction, U-Pb geochronology, biostratigraphy, Triassic-Jurassic boundary, Queen Charlotte Islands.

\section{INTRODUCTION}

The Triassic-Jurassic (Tr-J) boundary is marked by one of the five biggest mass extinction events, when an estimated $80 \%$ of species were lost (Sepkoski, 1996), but thus far it has been the least studied major extinction (Hallam, 1996a). The preserved marine geologic record is scanty because an exceptionally low sea level resulted in a dearth of reasonably continuous sedimentary successions across the Tr-J transition. In contrast, continental environments, which are often underrepresented in the rock record, have a remarkably well documented history across the Tr-J boundary (Olsen et al., 1996a). Studies of mass extinctions have implicitly assumed synchronous events in terrestrial and marine environments. For the end-Triassic, dramatic changes in both realms were documented (Olsen et al., 1987; Fowell and Olsen, 1993; Hallam, 1990); there is meager independent evidence for precise time correlation. Accurate timing of marine biotic events is necessary for understanding the processes of mass extinction, but obtaining these data has proved difficult. Recent advances in refining other parts of the geologic time scale employed high-precision $\mathrm{U}-\mathrm{Pb}$ zircon geochronology of volcanic ash layers embedded in fossiliferous sedimentary rocks (e.g., Pálfy et al., 1997; Bowring et al., 1998). Using this approach, we present crucial results for the Tr-J boundary. The refined time frame provides new insight into the end-Triassic mass extinction.

*Present address: Hungarian Natural History Museum, P.O. Box 137, H-1431, Budapest, Hungary. E-mail:palfy@paleo.nhmus.hu.

\section{DATING OF A MARINE TRIASSIC- JURASSIC BOUNDARY SECTION}

The Sandilands Formation in the Queen Charlotte Islands in western Canada consists of thinbedded alternating shale and siltstone, and ranges in age from Rhaetian (Late Triassic) through early Pliensbachian (Early Jurassic) (Cameron and Tipper, 1985; Desrochers and Orchard, 1991; Pálfy et al., 1994). It records an apparently uninterrupted Tr-J transition known at two locales, Kunga Island and Kennecott Point (Tipper et al., 1994). The section at the southeast shore of Kunga Island is one of the four sites proposed as candidates for the global stratotype section and point of the base of Jurassic.

\section{U-Pb Geochronology}

Common light colored layers within the Sandilands Formation were suggestive of a volcanic ash origin (Cameron and Tipper, 1985). Immediately below the Tr-J boundary on Kunga Island, we located and sampled a $3.5 \mathrm{~cm}$ thick tuff layer. Its undulatory but sharp base and top, graded texture, and the presence of crystals and small mudstone rip-up clasts indicate a reworked, waterlain volcanic ash bed.

The sample yielded a homogeneous zircon population that was subdivided into eight multigrain fractions for $\mathrm{U}-\mathrm{Pb}$ geochronology. Zircons separated from the tuff consisted of colorless grains of excellent clarity, without visible cores or zoning, and containing only very rare inclusions. Morphologies ranged continuously from anhedral and slightly resorbed, oval to elongate grains to euhedral, simple, stubby prismatic to elongate needle-like or tabular crystals, con- sistent with their volcanic origin. We processed $\sim 30 \mathrm{~kg}$ of rock. Standard procedures used in mineral separation, zircon chemistry, mass spectrometry, and data reduction were described elsewhere (Mortensen et al., 1995). U-Pb zircon dating was carried out in the Geochronology Laboratory of the University of British Columbia. $\mathrm{U}$ and $\mathrm{Pb}$ laboratory blanks were $\sim 1$ and $8 \mathrm{pg}$ during analysis of the first batch of samples (fractions with suffix 1) and 1 and 2 pg for the second batch (fractions with suffix 2). Analytical results are summarized in Table 1. Fractions A2, B2, and D1 are concordant and overlapping, and the others exhibit various degrees of discordance (Fig. 1). Fraction E2 clearly had an inherited component of older $\mathrm{Pb}$. The remaining four fractions (B1, C1, C2, and D2), scattered below and to the right of the cluster of concordant analyses on the concordia diagram, were likely affected by minor inheritance as well as $\mathrm{Pb}$ loss. The three concordant fractions contain $6.2 \%-6.4 \%$ radiogenic ${ }^{208} \mathrm{~Pb}$, whereas all other fractions have values $>7 \%$. The highest percentage of ${ }^{208} \mathrm{~Pb}$ is noted in fraction E2 that clearly carried inherited $\mathrm{Pb}$. Thus the ${ }^{208} \mathrm{~Pb}$ content, which reflects the $\mathrm{Th} / \mathrm{U}$ ratio in the zircons, appears to be useful to detect slight geochemical differences between concordant and discordant fractions and supports the inference of correlated inheritance and $\mathrm{Pb}$ loss in the discordant ones. We interpret the weighted mean ${ }^{206} \mathrm{~Pb} /{ }^{238} \mathrm{U}$ age of the three concordant fractions, $199.6 \pm 0.3 \mathrm{Ma}$, as the best estimate of the crystallization age of the tuff. The error is quoted at the $2 \sigma$ level of uncertainty. Uncertainty in spike calibration is propagated through the age calculation, but the decay constant errors are not included.

\section{Biochronology}

The Tr-J boundary in the Queen Charlotte Islands is recognized through integrated ammonoid, radiolarian, and conodont biochronology (Tipper et al., 1994; Carter, 1993; Carter et al., 1998). New fossil finds from Kunga Island have established a precise biochronologic age for the isotopically dated tuff (Fig. 2). The tuff is very near the top of the latest Triassic Globolaxtorum tozeri radiolarian zone (equivalent of the ammonoid standard Crickmayi zone), on the basis of an abundant and diverse fauna. The last appearance of $G$. tozeri is $5 \mathrm{~m}$ above the tuff, whereas the 
TABLE 1. U-Pb ZIRCON ANALYTICAL DATA FOR A TUFF FROM KUNGA ISLAND*

\begin{tabular}{|c|c|c|c|c|c|c|c|c|c|c|c|c|}
\hline \multirow[t]{2}{*}{ Fraction $^{\dagger}$} & \multirow{2}{*}{$\begin{array}{c}\text { Weight } \\
\text { (mg) }\end{array}$} & \multirow{2}{*}{$\begin{array}{c}U \\
(\mathrm{ppm})\end{array}$} & \multirow{2}{*}{$\begin{array}{c}\mathrm{Pb}^{\S} \\
(\mathrm{ppm})\end{array}$} & \multirow{2}{*}{$\frac{{ }^{206} \mathrm{~Pb}^{\#}}{{ }^{204} \mathrm{~Pb}}$} & \multicolumn{2}{|c|}{$\mathrm{Pb}^{* *}{ }^{208} \mathrm{~Pb}^{\dagger t}$} & \multicolumn{3}{|c|}{$\begin{array}{c}\text { Isotopic ratios } \\
(\%, \pm 1 \sigma)\end{array}$} & \multicolumn{3}{|c|}{$\begin{array}{c}\text { Isotopic ages } \\
\left(\mathrm{Ma}_{1} \pm 2 \sigma\right)\end{array}$} \\
\hline & & & & & $(\mathrm{pg})$ & $\%$ & ${ }^{206} \mathrm{~Pb} / 238 \mathrm{U}$ & ${ }^{207} \mathrm{~Pb} /{ }^{235} \mathrm{U}$ & ${ }^{207} \mathrm{~Pb} /{ }^{206} \mathrm{~Pb}$ & ${ }^{206} \mathrm{~Pb} /{ }^{238} \mathrm{U}$ & ${ }^{207} \mathrm{~Pb} / 235 \mathrm{U}$ & ${ }^{207} \mathrm{~Pb} / 206 \mathrm{~Pb}$ \\
\hline $\mathrm{A} 2$ cc,N2,p & 0.050 & 179 & 5 & 5483 & 3 & 6.4 & $0.03146(0.12)$ & $0.2174(0.20)$ & $0.05011(0.12)$ & $199.7(0.5)$ & $199.7(0.7)$ & $200.1(5.4)$ \\
\hline $\mathrm{B} 1 \mathrm{c}, \mathrm{m}, \mathrm{N} 1, \mathrm{e}$ & 0.058 & 165 & 5 & 2513 & 8 & 7.0 & $0.03127(0.10)$ & $0.2166(0.24)$ & 0.05025 & $198.5(0.4)$ & $99.1(0.9)$ & $206.7(8.3)$ \\
\hline $\mathrm{B} 2 \mathrm{c,N} 2, \mathrm{p}$ & 0.032 & 180 & 5 & 4388 & 3 & 6.2 & $0.03142(0.13)$ & $0.2170(0.20)$ & $0.05009(0.14)$ & $199.4(0.5)$ & $199.4(0.7)$ & $199.3(6.4)$ \\
\hline $\mathrm{C} 1 \mathrm{f}, \mathrm{N} 2, \mathrm{p}$ & 0.090 & 166 & 5 & 3181 & 9 & 7.1 & $0.03125(0.10)$ & $0.2166(0.20)$ & $0.05029(0.14)$ & $198.3(0.4)$ & $199.1(0.7)$ & $208.3(6.5)$ \\
\hline $\mathrm{C} 2 \mathrm{~m}, \mathrm{~N} 2, \mathrm{p}$ & 0.035 & 183 & 6 & 5847 & 2 & 7.2 & $0.03137(0.11)$ & $0.2182(0.18)$ & $0.05045(0.11)$ & $199.1(0.4)$ & $200.5(0.7)$ & $215.9(5.0)$ \\
\hline D1 c,m,N2,p & 0.058 & 143 & 4 & 1639 & 10 & 6.4 & $0.03144(0.10)$ & $0.2172(0.25)$ & $0.05011(0.19)$ & $199.6(0.4)$ & $199.6(0.9)$ & $200.0(8.7)$ \\
\hline D2 c,m,N2,p,e & 0.027 & 165 & 5 & 2324 & 4 & 7.3 & $0.03143(0.13)$ & $0.2197(0.24)$ & $0.05070(0.16)$ & $199.5(0.5)$ & $201.7(0.9)$ & $227.3(7.4)$ \\
\hline $\mathrm{E} 2 \mathrm{f}, \mathrm{p}, \mathrm{e}$ & 0.032 & 200 & 6 & 5361 & 2 & 7.5 & $0.03219(0.12)$ & $0.2238(0.20)$ & $0.05042(0.14)$ & $204.3(0.5)$ & $205.1(0.8)$ & $214.6(6.4)$ \\
\hline $\begin{array}{c}\text { separator sideslo } \\
\text { character codes: } \\
\text { § Radiogeni } \\
\text { \# Measured } \\
{ }^{* *} \text { Total com } \\
\text { †† Radiogen } \\
\text { \$§ Corrected }\end{array}$ & $\begin{array}{l}\mathrm{e}=\text { elon } \\
\text { ic } \mathrm{Pb} \text {. } \\
\text { ratio cor }\end{array}$ & $\begin{array}{l}\text { late, } p= \\
\text { ected fo } \\
\text { analys }\end{array}$ & $\begin{array}{l}\text { spike a } \\
\text { s based }\end{array}$ & d Pb fra & ionatic & $0.35 \%$ & $\begin{array}{l}\% / a m u( \pm 0.07 \%) \\
\text { tion. }\end{array}$ & the analog [ & collector and 0. & b/amu $( \pm 0.1$ & or the Fara & collector. \\
\hline
\end{tabular}

total thickness of the zone is $27 \mathrm{~m}$. The next higher collection, $1.5 \mathrm{~m}$ farther upsection, yielded abundant radiolarians of a depauperate, markedly different radiolarian assemblage of the earliest Hettangian Canoptum merum zone. This zone is correlated with the Planorbis Zone, the first standard chronozone of the Jurassic. Conodonts, which went extinct at the end of the Triassic, are restricted to the lower part of the section. Conodont faunas are of low diversity but diagnostic to the Rhaetian. The highest collection, $4 \mathrm{~m}$ above the tuff, yielded Norigondolella, which at Kennecott Point ranges to slightly above a single occurrence of Misikella posthernsteini and the ammonoid Choristoceras nobile, both guide fossils of the terminal Triassic (Orchard, 1991; Tipper et al., 1994; Orchard and Tozer, 1997; M. J. Orchard, 1998, personal commun.). No Late Triassic ammonoid has been found yet in the studied section. Psiloceras sp., the oldest Jurassic ammonoid discovered, is from $9 \mathrm{~m}$ above the tuff. A specimen close to Psiloceras cf. primocostatum, the index species of the second-oldest Jurassic ammonoid zone in South America (von Hillebrandt, 1994), occurs $16.5 \mathrm{~m}$ above the tuff.

\section{AGE OF THE TRIASSIC-JURASSIC BOUNDARY}

The U-Pb age reported here provides a direct estimate for the age of the Tr-J boundary. Ages

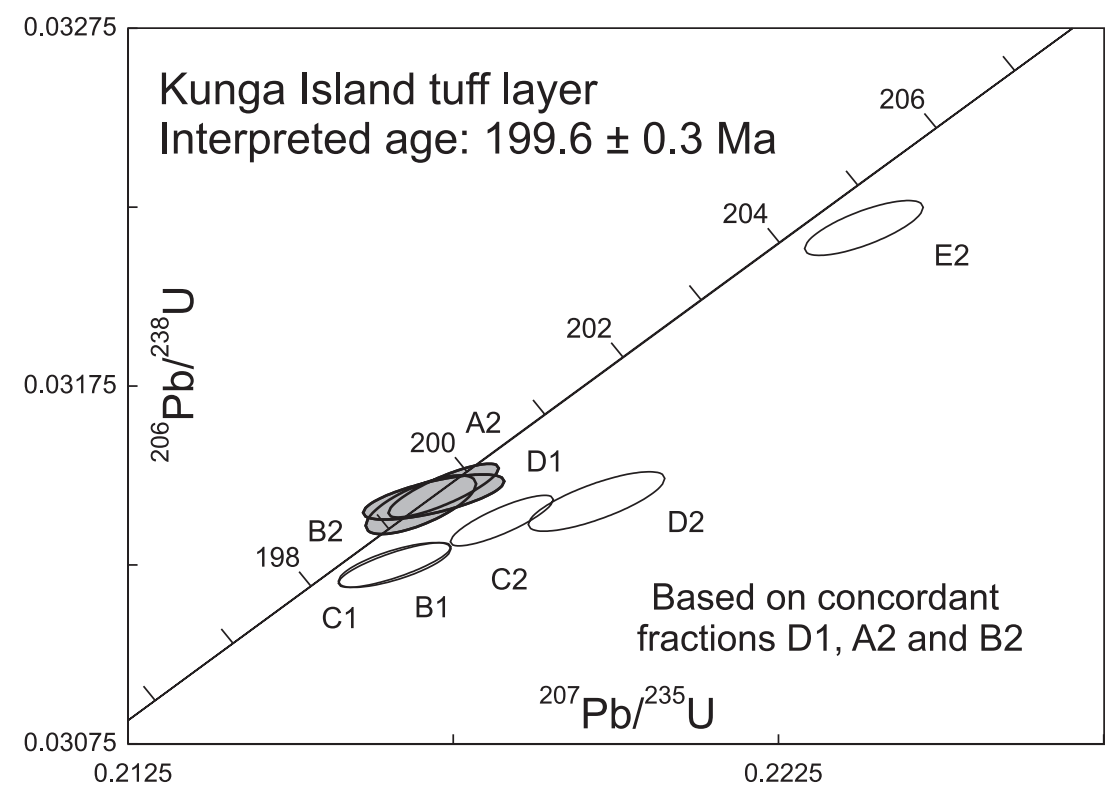

Figure 1. U-Pb concordia diagram of zircons from $3.5 \mathrm{~cm}$ thick tuff layer immediately below Triassic-Jurassic boundary, Sandilands Formation, Kunga Island. quoted by published time scales are invariably older by several million years. The two most widely used estimates are $208.0 \pm 7.5 \mathrm{Ma}$ (Harland et al., 1990) and $205.7 \pm 4.0 \mathrm{Ma}$ (Gradstein et al., 1994). Other time scales list 208 Ma (Palmer, 1983), $210 \mathrm{Ma}$ (Haq et al., 1987), and $203 \mathrm{Ma}$ (Odin, 1994) as the best boundary estimates. This inconsistency stems from interpolation between sparse samples that are poorly constrained stratigraphically. Several better constrained $\mathrm{U}-\mathrm{Pb}$ dates were recently obtained from marine island-arc terranes of the North American Cordillera (Table 2). These dates were not considered in previous time scales, but they convincingly support our conclusion that the true age of the Tr-J boundary is close to $200 \mathrm{Ma}$.

\section{COMPARISON WITH THE CONTINENTAL RECORD}

Precise $\mathrm{U}-\mathrm{Pb}$ dates were also published from three volcanic units within the continental Newark Supergroup in eastern North America (Dunning and Hodych, 1990; Hodych and Dunning, 1992). The North Mountain Basalt was dated as $201.7+1.4 /-1.1 \mathrm{Ma}$, whereas the Palisades and Gettysburg sills yielded ages of 200.9 $\pm 1.0 \mathrm{Ma}$ and $201.3 \pm 1.0 \mathrm{Ma}$, respectively. On the basis of geochemical and field evidence, the Palisades sill appears to have fed the lowermost flows of the Orange Mountain Basalt (Ratcliffe, 1988). The extrusive volcanic rocks postdate the palynologically defined Tr-J boundary (Fowell and Olsen, 1993) by only 20-40 k.y., on the basis of cyclostratigraphic evidence (Olsen et al., 1996b). Vertebrate extinction, as deduced from tetrapod remains (Olsen et al., 1987) and their trace fossil record (Silvestri and Szajna, 1993), is coincident with the peak in floral turnover. Consequently, $201 \mathrm{Ma}$ has been suggested as the age 


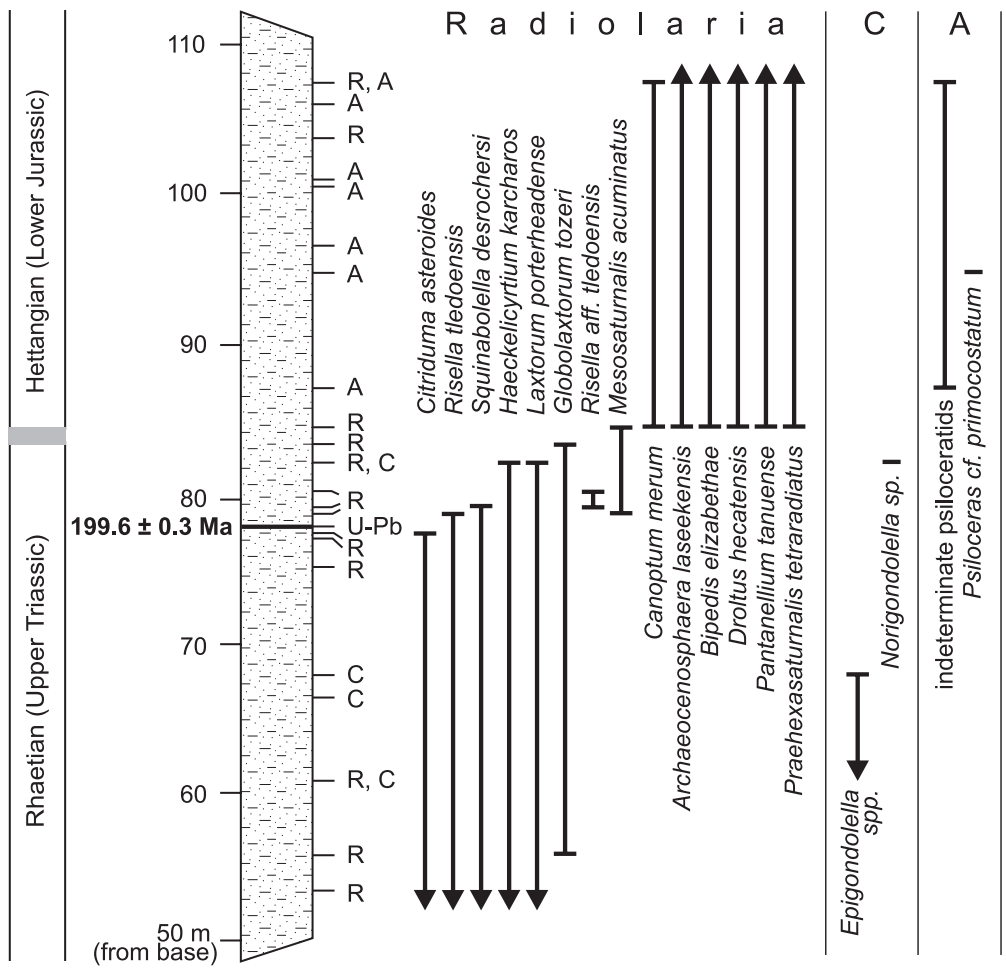

Figure 2. Position of U-Pb dated tuff layer (heavy black line) and biostratigraphy of Triassic-Jurassic boundary section on Kunga Island. Occurrences of key radiolarian $(\mathrm{R})$, conodont $(\mathrm{C})$, and ammonite $(\mathrm{A})$ taxa and section measurements are compiled from published data (Tipper et al., 1994; Carter, 1993; Carter et al., 1998), complemented by data from new collections.

of the continental Tr-J boundary (Olsen et al., 1996b). The three overlapping isotopic ages and their respective errors suggest that the terrestrial extinction occurred no later than $200.6 \mathrm{Ma}$ (i.e., the young end of the error range of the oldest of the three ages, the North Mountain Basalt). As demonstrated here, the marine event, constrained by the U-Pb age from Kunga Island, did not occur before 199.9 Ma. The crisis of terrestrial biota preceded that of the marine realm by at least 700 k.y. This is the first evidence of such temporal dichotomy within a major mass extinction.

\section{DISCUSSION}

Apart from additional isotopic dating, an independent test for the asynchrony of marine and terrestial extinction events may eventually be provided by magnetostratigraphy. In lacustrine sediments of the Newark basin, the palynologically defined boundary occurs immediately above a short reverse interval (coded E23n.1r; Kent et al., 1995). We predict that in marine sections, the base of Jurassic should be within the higher part of the protracted normal magnetochron E23n. To date, no paleomagnetic data have been reported from fully marine sections that span the Tr-J boundary.

Demonstrating the asynchrony of terrestrial and marine mass extinctions has profound implications. First, it argues against a single sudden and globally catastrophic cause, such as a bolide impact. Second, it raises the possibility of distinct and unrelated events on land and in the ocean. Despite the difference in timing, however, we consider it unlikely that the terminal Triassic terrestrial and marine mass extinctions were coincidentally closely spaced, unrelated phenomena. Extinction scenarios that invoke long-term environmental change remain consistent with the new evidence of temporal difference between terrestrial and marine events. Processes with a shorter response time or lower threshold in the more vulnerable terrestrial biota may account for the observed pattern. Further research is needed to identify complex feedback mechanisms whereby environmental change and concomitant terrestrial ecosystem collapse cascade into the marine realm with a delay of several hundred thousand years.

The timing of extensive basaltic volcanism around the Tr-J boundary offers an intriguing comparison with our results. The ${ }^{40} \mathrm{Ar} /{ }^{39} \mathrm{Ar}$ dating by Marzoli et al. (1999) documented that the Central Atlantic magmatic province records one of the most widespread volcanic episodes in Earth history, with a short-lived peak intensity at 200 Ma. The temporal coincidence of flood basalt volcanism and mass extinction should be further considered in studies of the end-Triassic biotic event.

If the Tr-J boundary is younger than previously thought, then the duration of the latest Triassic was probably longer than estimated in published time scales. The Rhaetian, a time of protracted decline for many fossil groups including the ammonites, bivalves, and conodonts (Hallam, 1996a), may have lasted several million years, although no isotopic ages are available to accurately constrain its duration. Timing of the Early Jurassic marine biotic recovery is better known. The early Hettangian (Planorbis Zone) is characterized by a low-diversity fauna worldwide and is perhaps best regarded as a postextinction lag or survival period. True recovery and diversification started in the middle Hettangian within many clades (Hallam, 1996b). Hettangian U-Pb dates from Alaska (Table 2) (Pálfy et al., 1999) indicate that recovery was under way within less than 2 m.y. Whether the apparent length of the biotic crisis and the delayed rebound are artifacts of inadequate sampling (Signor and Lipps, 1982; Erwin, 1998) remains to be tested.

TABLE 2. LIST OF RECENTLY PUBLISHED U-Pb ZIRCON DATES RELEVANT TO THE AGE OF THE TRIASSIC-JURASSIC BOUNDARY

\begin{tabular}{|c|c|c|c|c|c|}
\hline \multirow[t]{2}{*}{ Dated rock } & \multirow[t]{2}{*}{ Locality } & \multirow{2}{*}{$\begin{array}{l}\text { U-Pb age } \\
\text { (Ma) }\end{array}$} & \multicolumn{2}{|c|}{ Biochronologic age } & \multirow[t]{2}{*}{ Reference } \\
\hline & & & Maximum & Minimum & \\
\hline Tuff in Talkeetna Formation & Puale Bay, Alaska & $197.8 \pm 1.0$ & Middle Hettangian & Late Hettangian & Pálfy et al., 1999 \\
\hline Tuff in Talkeetna Formation & Puale Bay, Alaska & $197.8+1.2 /-0.4$ & Middle Hettangian & Late Hettangian & Pálfy et al., 1999 \\
\hline Tuff in Kamishak Formation & Puale Bay, Alaska & $200.8 \pm 2.8$ & Middle Hettangian & Middle Hettangian & Pálfy et al., 1999 \\
\hline Goldslide Porphyry (Goldslide Intrusions) & Stewart, B.C. & $197.6 \pm 1.9$ & Hettangian & Hettangian & Rhys et al., 1995 \\
\hline Tuff in Hazelton Group & Stewart, B.C & $199 \pm 2$ & Hettangian & Hettangian & Greig and Gehrels, 1995 \\
\hline "Biotite Porphyry" (Goldslide Intrusions) & Stewart, B.C & $201.8 \pm 0.5$ & Norian & Rhaetian & Greig et al., 1995 \\
\hline Griffith Creek volcanics & Spatsizi River, B.C. & $205.8 \pm 0.9$ & Norian & Rhaetian & Thorkelson et al., 1995 \\
\hline Griffith Creek volcanics & Spatsizi River, B.C. & $205.8+1.5 /-3.1$ & Norian & Rhaetian & Thorkelson et al,, 1995 \\
\hline
\end{tabular}




\section{ACKNOWLEDGMENTS}

We thank the personnel of the Gwaii Haanas National Park for permission to conduct field work on Kunga Island. R. R. Parrish gave invaluable help in selecting and collecting the sample for U-Pb dating. We benefited from discussions with $\mathrm{M}$. Orchard on conodon biochronology and A. von Hillebrandt on ammonoid taxonomy and biochronology. Reviews by P. R. Renne and S. D. Samson improved the manuscript. Financial support was provided through Natural Science and Engineering Research Council grants to Smith and Mortensen. Pálfy acknowledges support from the Hungarian Scientific Research Fund (grant F23451) and Collegium Budapest.

\section{REFERENCES CITED}

Bowring, S. A., Erwin, D. H., Jin, Z. G., Martin, M. W. Davidek, K., and Wang, W., 1998, U/Pb zircon geochronology and tempo of the end-Permian mass extinction: Science, v. 280, p. 1039-1045

Cameron, B. E. B., and Tipper, H. W., 1985, Jurassic stratigraphy of the Queen Charlotte Islands, British Columbia: Geological Survey of Canada Bulletin 365, 49 p.

Carter, E. S., 1993, Biochronology and paleontology of uppermost Triassic (Rhaetian) radiolarians, Queen Charlotte Islands, British Columbia, Canada: Mémoires de Géologie (Lausanne), v. $11,175 \mathrm{p}$

Carter, E. S., Whalen, P. A., and Guex, J., 1998, Biochronology and paleontology of Lower Jurassic (Hettangian and Sinemurian) radiolarians, Queen Charlotte Islands, British Columbia: Geological Survey of Canada Bulletin 496, 162 p.

Desrochers, A., and Orchard, M. J., 1991, Stratigraphic revisions and carbonate sedimentology of the Kunga Group (Upper Triassic-Lower Jurassic), Queen Charlotte Islands, British Columbia, in Woodsworth, G. J., ed., Evolution and hydrocarbon potential of the Queen Charlotte Basin, British Columbia: Geological Survey of Canada Paper 90-10, p. 163-172.

Dunning, G. R., and Hodych, J. P., 1990, U/Pb zircon and baddeleyite ages for the Palisades and Gettysburg sills of the northeastern United States: Implications for the age of the Triassic-Jurassic boundary: Geology, v. 18, p. 795-798.

Erwin, D. H., 1998, The end and the beginning: Recoveries from mass extinctions: Trends in Ecology \& Evolution, v. 13, p. 344-349.

Fowell, S. J., and Olsen, P. E., 1993, Time calibration of Triassic/Jurassic microfloral turnover, eastern North America: Tectonophysics, v. 222 p. 361-369

Gradstein, F. M., Agterberg, F. P., Ogg, J. G., Hardenbol, J., van Veen, P., Thierry, J., and Huang, Z., 1994, A Mesozoic time scale: Journal of Geophysical Research, v. 99, p. 24,051-24,074.

Greig, C. J., and Gehrels, G. E., 1995, U-Pb zircon geochronology of Lower Jurassic and Paleozoic Stikinian strata and Tertiary intrusions, northwestern British Columbia: Canadian Journal of Earth Sciences, v. 33, p. 1155-1171.

Greig, C. J., McNicoll, V. J., Anderson, R. G., Daubeny, P. H., Harakal, J. E., and Runkle, D., 1995, New $\mathrm{K}-\mathrm{Ar}$ and $\mathrm{U}-\mathrm{Pb}$ dates for the Cambria Icefield area, northwestern British Columbia, Current Research, Part A: Geological Survey of Canada Paper 95-1A, p. $97-103$.

Hallam, A., 1990, The end-Triassic mass extinction event, in Sharpton, V. L., and Ward, P. D., eds., Global catastrophes in Earth history; an interdisciplinary conference on impacts, volcanism, and mass mortality: Geological Society of America Special Paper 247, p. 577-583.

Hallam, A., 1996a, Major bio-events in the Triassic and Jurassic, in Walliser, O. H., ed., Global events and event stratigraphy in the Phanerozoic: Berlin, Springer, p. 265-283.

Hallam, A., 1996b, Recovery of the marine fauna in Europe after the end-Triassic and early Toarcian mass extinctions, in Hart, M. B., ed., Biotic recovery from mass extinction events: Geological Society [London] Special Publication 102, p. 231-236.

Haq, B. U., Hardenbol, J., and Vail, P. R., 1987, Chronology of fluctuating sea levels since the Triassic: Science, v. 235, p. 1156-1167

Harland, W. B., Armstrong, R. L., Cox, A. V., Craig, L. E., Smith, A. G., and Smith, D. G., 1990, A geologic time scale 1989: Cambridge, Cambridge University Press, $263 \mathrm{p}$.

Hodych, J. P., and Dunning, G. R., 1992, Did the Manicouagan impact trigger end-of-Triassic mass extinction?: Geology, v. 20, p. 51-54

Kent, D. V., Olsen, P. E., and Witte, W. K., 1995, Late Triassic-earliest Jurassic geomagnetic polarity sequence and paleolatitudes from drill cores in the Newark rift basin, eastern North America: Journal of Geophysical Research, v. 100 p. $14,965-14,998$

Marzoli, A., Renne, P. R., Piccirillo, E. M., Ernesto, M., Bellieni, G., and De Min, A., 1999, Extensive 200-million-year-old continental flood basalts of the Central Atlantic Magmatic Province: Science, v. 284 , p. $616-618$.

Mortensen, J. K., Ghosh, D. K., and Ferri, F., 1995 , $\mathrm{U}-\mathrm{Pb}$ geochronology of intrusive rocks associated with copper-gold porphyry deposits in the Canadian Cordillera, in Schroeter, T. G., ed., Porphyry deposits of the northwestern Cordillera of North America: Canadian Institute of Mining, Metallurgy and Petroleum Special Volume 46, p. $142-158$

Odin, G. S., 1994, Geological time scale: Paris, Académie des Sciences Comptes Rendus, ser. II, v. 318, p. 59-71.

Olsen, P. E., Shubin, N. H., and Anders, M. H., 1987, New Early Jurassic tetrapod assemblages constrain Triassic-Jurassic tetrapod extinction event: Science, v. 237, p. 1025-1029.

Olsen, P. E., Kent, D. V., Cornet, B., Witte, W. K., and Schlische, R. W., 1996a, High-resolution stratigraphy of the Newark rift basin (early Mesozoic, eastern North America): Geological Society of America Bulletin, v. 108, p. 40-77.

Olsen, P. E., Schlische, R. W., and Fedosh, M. S., 1996b, 580 ky duration of the Early Jurassic flood basalt event in eastern North America estimated using Milankovitch cyclostratigraphy, in Morales, M. ed., The continental Jurassic: Museum of Northern Arizona Bulletin 60, p. 11-22.

Orchard, M. J., 1991, Late Triassic conodont biochronology and biostratigraphy of the Kunga Group, Queen Charlotte Islands, British Columbia, in Woodsworth, G. J., ed., Evolution and hydrocarbon potential of the Queen Charlotte Basin, British Columbia: Geological Survey of Canada Paper 90-10, p. 173-194.

Orchard, M. J., and Tozer, E. T., 1997, Triassic conodont biochronology, its calibration with the ammonoid standard, and a biostratigraphic summary for the Western Canada Sedimentary Basin: Bulletin of Canadian Petroleum Geology, v. 45, p. 675-692.

Pálfy, J., Smith, P. L., and Tipper, H. W., 1994, Sinemurian (Lower Jurassic) ammonoid biostratigraphy of the Queen Charlotte Islands, western Canada, in Cariou, E., and Hantzpergue, P., eds., Geobios Mémoire Spécial: Lyons, Université Claude Bernard, v. 17, p. 385-393.

Pálfy, J., Parrish, R. R., and Smith, P. L., 1997, A U-Pb age from the Toarcian (Lower Jurassic) and its use for time scale calibration through error analysis of biochronologic dating: Earth and Planetary Science Letters, v. 146, p. 659-675.

Pálfy, J., Smith, P. L., Mortensen, J. K., and Friedman, R. M., 1999, Integrated ammonite biochronology and $\mathrm{U}-\mathrm{Pb}$ geochronometry from a basal Jurassic section in Alaska: Geological Society of America Bulletin, v. 111, p. 1537-1549.

Palmer, A. R., 1983, The Decade of North American Geology 1983 geologic time scale: Geology, v. 11, p. 503-504.

Ratcliffe, N. M., 1988, Reinterpretation of the relationships of the western extension of the Palisades sil to the lava flows at Ladentown, New York, based on new core data, in Froelich, A. J., and Robinson, G. R., eds., Studies of the early Mesozoic basins of the eastern United States: U.S. Geological Survey Bulletin 1776, p. 113-135.

Rhys, D. A., Sieb, M., Frostad, S. R., Swanson, C. L., Prefontaine, M. A., Mortensen, J. K., and Smit, H. Q., 1995, Geology and setting of the Red Mountain gold-silver deposits, northwestern British Columbia, in Schroeter, T. G., ed., Porphyry deposits of the northwestern Cordillera of North America: Canadian Institute of Mining, Metallurgy and Petroleum Special Volume 46, p. 811-828.

Sepkoski, J. J., Jr., 1996, Patterns of Phanerozoic extinction: A perspective from global data bases, in Walliser, O. H., ed., Global events and event stratigraphy in the Phanerozoic: Berlin, Springer, p. 35-51.

Signor, P. W., and Lipps, J. H., 1982, Sampling bias, gradual extinction patterns and catastrophes in the fossil record, in Silver, L. T., and Schultz, P. H., eds., Geological implications of impacts of large asteroids and comets on the Earth: Geological Society of America Special Paper 190, p. 291-296.

Silvestri, S. M., and Szajna, M. J., 1993, Biostratigraphy of vertebrate footprints in the Late Triassic section of the Newark basin, Pennsylvania: Reassessment of stratigraphic ranges, in Lucas, S. G., and Morales, M., eds., The nonmarine Triassic: New Mexico Museum of Natural History and Science Bulletin 3, p. 439-445.

Stacey, J. S., and Kramers, J. D., 1975, Approximation of terrestrial lead isotope evolution by a two-stage model: Earth and Planetary Science Letters, v. 26 , p. 207-221.

Thorkelson, D. J., Mortensen, J. K., Marsden, H., and Taylor, R. P., 1995, Age and tectonic setting of Early Jurassic episodic volcanism along the northeastern margin of the Hazelton Trough, northern British Columbia, in Miller, D. M., and Busby, C., eds., Jurassic magmatism and tectonics of the North American Cordillera: Geological Society of America Special Paper 299, p. 83-94.

Tipper, H. W., Carter, E. S., Orchard, M. J., and Tozer, E. T., 1994, The Triassic-Jurassic (T-J) boundary in Queen Charlotte Islands, British Columbia defined by ammonites, conodonts and radiolarians, in Cariou, E., and Hantzpergue, P., eds., Geobios Mémoire Spécial: Lyon, Université Claude Bernard, v. 17, p. 485-492.

von Hillebrandt, A., 1994, The Triassic/Jurassic boundary and Hettangian biostratigraphy in the area of the Utcubamba Valley (northern Peru), in Cariou, E., and Hantzpergue, P., eds., Geobios Mémoire Spécial: Lyon, Université Claude Bernard, v. 17, p. 297-307.

Manuscript received May 13, 1999

Revised manuscript received August 17, 1999

Manuscript accepted September 2, 1999 